\title{
Çevrimiçi Ortamda Yürütülen Öğretimde Planlama ve Değerlendirme Dersine Yönelik Öğrenci Görüşleri ${ }^{1}$
}

\author{
Students' Opinions on Online 'Instructional Planning and Evaluation' Course ${ }^{2}$ \\ Meral GÜVEN \\ Anadolu University, Turkey \\ mguven@anadolu.edu.tr
}

$\ddot{\mathbf{O z}}$

$\mathrm{Bu}$ araştırmanın amacı, çevrimiçi ortamda düzenlenen "Öğretimde Planlama ve Değerlendirme” dersinin amaç, içerik, öğretme- öğrenme süreci ve değerlendirme süreçlerine yönelik öğrenci görüşlerini belirlemektir. Tarama yöntemi kullanılarak gerçekleştirilen bu çalışma, 2014-2015 öğretim yılında güz-bahar dönemlerinde Anadolu Üniversitesi Eğitim Bilimleri Enstitüsünde açılan Öğretimde Planlama ve Değerlendirme dersini alan gönüllülük esasına göre görüşlerine başvurulan 69 doktora öğrencisi ile gerçekleştirilmiştir. Araştırmada açık uçlu anket aracılığıyla toplanan veriler betimsel analiz tekniğine göre çözümlenmiştir. Araştırma sonucunda, doktora öğrencileri Öğretimde Planlama ve Değerlendirme dersinin amaçlarına, içeriğine, öğrenme- öğretme sürecine ve değerlendirme süreçlerine yönelik genel olarak olumlu görüş bildirmişlerdir. Doktora öğrencilerinin dersin amaçlarına yönelik yeterli, etkili, anlaşılır, ulaşılır olduğu biçiminde, içeriğine yönelik faydalı, ilgi çekici, anlaşılır, açık, net ve yeterli gibi görüşleri, öğrenme - öğretme sürecine yönelik online olmasının olumlu olduğu, açık, etkileşime dayalı, öğretici olduğu gibi görüşleri ve değerlendirmeye yönelik ise yeterli olduğu, değerlendirmenin amacina uygun, objektif olduğu yönünde görüşleri bulunmaktadır.

\footnotetext{
${ }^{1}$ Bu çalışma 26 - 28 Haziran 2015 tarihinde St Petersburg’ta düzenlenen 4. Uluslararası Eğitim Konferans'ında sunulan sözlü bildirinin geliştirilmiş halidir.

${ }^{2}$ Araştırma makalesi, ìlk gönderim tarihi: 29.12.2015 Kabul tarihi: 22.01.2015
} 
Anadolu Journal of Educational Sciences International, January 2016, 6(1)

Anahtar sözcükler: Program değerlendirme, Çevrimiçi öğrenme, Öğretim, Öğretimde Planlama ve Değerlendirme Dersi 


\begin{abstract}
The aim of this study is to reveal the students' opinions on the aim, content, learning-teaching processes, and evaluation processes of the online 'Instructional Planning and Assessment' course. This survey research was conducted with the voluntary participation of $69 \mathrm{PhD}$ students who took the 'Instructional Planning and Assessment' online course offered by Anadolu University Institute of Educational Sciences in 2014-2015 fall and spring semesters. In this research, the data collected through open-ended questionnaires were analyzed with descriptive data analysis technique. As a result of the study, doctoral students stated positive opinions about the aims, content, learning-teaching process and evaluation processes of 'Instructional Planning and Evaluation' course. Doctoral students stated that the aims of the course are sufficient, effective, comprehensible and reachable; the content of the course is useful, interesting, comprehensible, clear and sufficient; the online learning-teaching process is positive, clear, interaction-based and informative; evaluation of the course is sufficient, congruent with the aims and objective.
\end{abstract}

Keywords: Curriculum development, online learning, teaching, Instructional Planning and Assessment

\title{
Giriş
}

Son y1llarda değişen ve farklılaşan dünya ile birlikte bireylerden beklenen özelliklere yenileri eklenmiş; bireylerin, araştıran, sorgulayan, problem çözebilen, eleştirel düşünebilen, öğrenmeyi öğrenen, bilgiyi üretebilen, yaratıcı, esnek, teknolojiden faydalanabilen, düşündüklerini kolayca ifade edebilen özelliklere sahip olmaları beklenmeye başlanmıştır. Bugünün istihdam koşulları bireylerin hangi bilgi ve becerilere sahip olmalarının gerektiği konusunda belirleyici bir role sahiptir. Bu özellikleri geliştirmede önemli bir işlevi olduğu kabul edilen öğreticilerin 
de değişme ve gelişmeleri anlayabilen, yorumlayabilen, etkililik ve kalite gibi değer ve davranışları özümseyen bireylerden oluşması, eğitim hizmetlerinde kalitenin sağlanması açısından önemli bir beklentidir.

Teknolojide hızlı gelişmeler yaşandığı için bireylerin sahip olduğu teknik beceriler de kolayca güncelliğini yitirebilmektedir. Bu tür bilgi ve becerilere gereksinim duyan bireylerin bu gereksinimlerini karşılamada sürekli, esnek ve kesintisiz eğitimlerin sunulabildiği çevrim-içi öğrenme ortamları etkili bir şekilde kullanılabilir. Öğrenme sürecinin bir kısmı bugün elektronik öğrenme ortamlarına taşınmış ve e-öğrenme bireyin yaşantısının bir parçası haline gelmiştir. E-öğrenme kavramı “öğretim etkinliklerinin elektronik ortamlarda yürütülmesi veya bilgi ve becerilerin elektronik teknolojiler aracılı̆̆ıla aktarılması olarak tanımlanabilir" (Gülbahar, 2009; Bender, 2003). E-öğrenmenin kapsamı içinde yer alan ve internet tabanlı öğrenme, web-tabanlı öğrenme, online öğrenme gibi isimlerle anılan çevrimiçi öğrenme, bilgi ve iletişim teknolojilerindeki gelişmelere paralel olarak büyük bir hızla gelişmektedir (Çardak, 2012).

Çevrimiçi öğrenme, içeriğin, öğretme etkinliklerinin ve öğrenme yaşantılarının öğrencilere bilgisayar ağlarının kullanımı ile sunulduğu bir öğrenme durumunu ifade etmektedir (Çalışkan, 2002). Çevrimiçi öğrenme süreci yüz-yüze öğrenme yaşantılarına ve bilgisayar temelli öğrenme durumlarına değer katan yeni araçlar sunar (Chorfi ve Jemni, 2004). Çevrimiçi ortamlar, öğrenenlerin etkin bir şekilde öğrenme sürecinin içine çekildiği, değişik seçenekler karşısında kararlar vermek durumunda olduğu ve bunun sonucunda değişik etkinliklere katıldığı ortamlar olarak düşünülmelidir. Bu açıdan çevrimiçi öğrenme ortamlarının öğrenenlere etkili bir iletişim ortamı sağlaması, açık etkileşim sağlaması, destekleyici bir öğrenme ortamı yaratması, 
Anadolu Journal of Educational Sciences International, January 2016, 6(1)

etkileşimi kolaylaştıracak ortamlar yaratması, yapıcı öğrenme yaklaşımlarını uygulamak gibi özellikleri (Aydın, 2002) taşıması beklenmektedir.

Çevrimiçi öğrenme ortamları gerek lisans gerekse lisansüstü derslerde yoğun olarak kullanılmaktadır. Bununla birlikte, Yüksek Öğretim Kurulu tarafından belirlenen Eğitim Bilimleri Enstitüsü dışında kalan enstitülerde öğrenim gören doktora öğrencilerinin almak zorunda oldukları "Gelişim ve Öğrenme" ile "Öğretimde Planlama ve Değerlendirme" dersleri Anadolu Üniversitesinde çevrimiçi ortamda güz ve bahar dönemlerinde yürütülmektedir. Gerek Anadolu Üniversitesi gerekse diğer üniversitelerin doktora öğrencilerinin aldıkları bu dersler onları öğretim üyeliğine hazırlık amacı taşımaktadır.

Öğretimde Planlama ve Değerlendirme dersinin içeriği YÖK tarafından "Temel program geliştirme kavramları ve süreçleri, ders programı, yıllık, ünite, günlük planların geliştirilmesi, içerik seçimi ve organizasyonu, ögretim yöntemleri ve stratejileri, materyallerin özellikleri ve seçimi, ölçme ve değerlendirme, değerlendirme yaklaşımları, test türleri, izleme ve başarı testlerinin geliştirilmesi, sınav sorusu yazma teknikleri, not verme” olarak belirlenmiştir (YÖK, 1998).

Öğreticilik becerisi oldukça kapsamlı olup; dersin amaçlarının belirlenmesinden öğrencinin değerlendirilmesine kadar birçok temel beceriyi içerisinde barındırmaktadır. Öğretimde Planlama ve Değerlendirme dersi amaçların belirlenmesi, içeriğin oluşturulması, öğrenci özelliklerine uygun öğrenme - öğretme ortamının düzenlenmesi, öğrencilerin ilgilerinin gözönüne alınması, etkili bir değerlendirme sürecine yönelik olarak düzenlenmektedir (Senemoğlu, 1997; Demirel, 2004). Öğretimde Planlama ve Değerlendirme dersine yönelik düzenlenen çevrimiçi öğrenme ortamlarının Eğitim Bilimleri Enstitüsü dışında kalan 
enstitülerde öğrenim gören doktora öğrencileri tarafından nasıl görüldüğünün belirlenmesi önemli görülmektedir. Bununla birlikte, daha önce bu amaçla bir çalışmanın yapılmış olmaması da çalışmanın gerçekleştirilmesine gerekçe oluşturmuştur. Bu araştırmanın amacı, çevrimiçi ortamda düzenlenen "Öğretimde Planlama ve Değerlendirme” dersinin amaç, içerik, öğretmeöğrenme süreci ve değerlendirme süreçlerine yönelik öğrenci görüşlerini belirlemektir.

\section{Yöntem}

Çevrimiçi ortamda düzenlenen “Öğretimde Planlama ve Değerlendirme” dersinin amaç, içerik, öğretme- öğrenme süreci ve değerlendirme süreçlerine yönelik öğrenci görüşlerini belirlemek amacıyla çalışmada tarama yöntemi kullanılmıştır. Tarama yöntemi, konuyu kendi ortamı içerisinde ve olduğu gibi tanımlamaya ve betimlemeye çalışır (Karasar, 2015).

Bu amaçla çalışma, 2014-2015 öğretim yılında güz - bahar dönemlerinde Anadolu Üniversitesi Eğitim Bilimleri Enstitüsünde açılan Öğretimde Planlama ve Değerlendirme dersini alan ve gönüllülük esasına göre görüşlerine başvurulan 69 doktora öğrencisi ile gerçekleştirilmiştir. Bu doktora öğrencilerinin büyük bölümü Anadolu Üniversitesine devam etmekle birlikte Ege Üniversitesi, Bileceik Üniversitesi, Dumlupınar Üniversitesi, Ankara Üniversitesi gibi üniversitelere devam eden öğrencilerde bulunmaktadır. Yine doktora öğrencilerinin 26's1 güz, 43'ü de bahar döneminde yer almaktadırlar. Bununla birlikte, 31'i kadın, 38'i erkektir. Bununla birlikte, doktora öğrencilerinin 16'sı Sağlık Bilimleri Enstitüsüne, 22'si Sosyal Bilimler Enstitüsüne, 10’u Güzel Sanatlar Enstitüsüne, 20'si Fen Bilimleri Enstitüsüne ve 1'i de Anadolu Üniversitesi dışında farklı bir üniversitenin Uzay Bilimleri Enstitüsüne devam etmektedirler. 


\section{Verilerin Toplanılması}

Araştırmada veriler açık uçlu anket aracılığıyla toplanmıştır. Bu ankette doktora öğrencilerine Öğretimde Planlama ve Değerlendirme dersinin amaç, içerik, öğretme - öğrenme süreçleri ve değerlendirme süreçlerine yönelik görüşlerini belirlemeye yönelik dört soruya ve ek olarakta diğer görüşlerini belirlemeye yönelik bir soruya yer verilmiştir. Ayrıca, kişisel bilgilerini belirlemeye yönelik sorulara da yer verilmiştir. Bu anket soruları eğtim programları ve öğretim alanında doktorasını tamamlamış üç alan uzmana sunulmuş, uzmanların görüş birliği ile araştırma soruları geçerli kabul edilmiştir.

\section{Verilerin Çözümlenmesi}

Araştırmada açık uçlu anket aracılığıyla toplanan veriler, betimsel analiz tekniğine göre çözümlenmiştir. Betimsel analizde veriler, araştırma sorularına ya da araştırma sorularına dayalı oluşturulan temalara göre sunulabilir. Bu analizde katılımcıların görüşlerini çarpıcı bir biçimde yansıtmak amacıyla doğrudan alıntılar yapılır. Betimsel analiz sürecinde yapılan işlemler aşağıda açıklanmıştır (Yıldırım ve Şimşek, 2013):

- Verilerin dökümü: Verilerin çözümlenmesi aşamasında, açık uçlu ankete verilen yanıtlar araştırmacı tarafından çözümlenerek veri döküm formu oluşturulmuş, açık uçlu anket ve veri döküm formu bir uzmana verilerek yanlış ya da eksik bölümlerin kontrolü sağlanmıştır.

- Kodlama anahtarının oluşturulması ve kodlanması: Verilerin dökülmesi aşamasından sonra anket soruları temel alınarak ve bu soruların yanıtlarını kapsayacak seçeneklere yer verilerek veri kodlama anahtarı hazırlanmıştır. Araştırmanın katılımcıları olan doktora öğrencileri için K1, K2, K3,... gibi kodlar kullanılmıştır.

- Kodlamaların karşılaştırılması ve güvenilirlik: Kodlama süreci araştırmacı tarafından gerçekleştirildikten sonra alanda uzman bir kişi ile bir araya gelerek yapmış oldukları 
analizleri karşılaştırmış, görüş birliği ve görüş ayrılığı olan maddeleri belirlemiştir. Bu amaçla, araştırmanın güvenilirlik hesaplaması için Miles ve Huberman'ın (1994: 64) önerdiği güvenirlik formülü kullanılmıştır. Güvenirlik formülüyle hesaplanan sonucun \%70'in üzerinde olması durumunda (Miles ve Huberman, 1994: 64) değerlendiriciler arası güvenirliğin sağlanmış olduğu kabul edilmektedir. Bu araştırmada yapılan hesaplamalar sonucunda araştırmanın güvenirliği \% 90 çıkmış ve araştırma güvenilir kabul edilmiştir.

- Bulguların tanımlanması ve yorumlanması: Kodlama anahtarına göre işlenen veriler araştırma soruları doğrultusunda doğrudan alıntılarla desteklenerek bulgular tanımlanmış ve tanımlanan bu bulgular araştırmacı tarafından açıklanarak yorumlanmıştır.

\section{Bulgular ve Yorumları}

Bu bölümde araştırmanın amacına yönelik olarak bulgulara ve yorumlarına yer verilmiştir.

\section{Öğretimde Planlama ve Değerlendirme Dersinin Amaçlarına Yönelik Görüşler İle İlgili}

\section{Bulgular}

Araştırmada öncelikle Öğretimde Planlama ve Değerlendirme dersinin amaçlarına yönelik doktora öğrencilerine görüşleri sorulmuş, ortaya çıkan yanıtlarına Tablo 1'de yer verilmiştir. 
Tablo 1

Öğretimde Planlama ve Değerlendirme Dersinin Amaçlarına Yönelik Görüşler

\begin{tabular}{|c|c|}
\hline Amaçlara ilişkin Görüşler & f \\
\hline Öğrencilere hitap edecek insanlar için çok gerekli ve önemli bir derstir ve bunlar sağlanmıştır. & 16 \\
\hline Amaçlara ulaşılmıştır. & 14 \\
\hline Amaçlar etkilive anlaşlır biçimde verilmiştir. & 8 \\
\hline Amaçlar yeterlidir. & 8 \\
\hline Amaçlar öğrencilerin gereksinimlerine göre hazırlanmıştır. & 8 \\
\hline İyi bir öğretimin nasıl yapılacağını göstermiştir. & 8 \\
\hline Amaçlar yerinde ve uygun düzenlenmiştir. & 6 \\
\hline Amaçlar ve içerik birbirine uyumludur. & 6 \\
\hline Doğru amaçlar etrafında ders planlanmıştır. & 4 \\
\hline Derslerin planlı ve programlı biçimde yapılması amacını taşımaktadır. & 4 \\
\hline Öğretim yöntem ve tekniklerinin öğretilmesi amaçlanmıştır. & 4 \\
\hline Amaçlar gerçekleşmiştir. & 4 \\
\hline Dersin amaçları ile ders uyumludur. & 4 \\
\hline Uygulamaya yönelik amaçlar arttırılabilir. & 3 \\
\hline Doktora dersi olarak verilmesi uygundur. & 2 \\
\hline Öğretim kalitesini yükseltmek amacına ulaşmıştır. & 2 \\
\hline Amaçlar tam ve yeterlidir. & 2 \\
\hline Uygulamaya yönelik olması açısından olumludur. & 2 \\
\hline Öğretim elemanına doğru bir tarz kazandırmaya yönelik başarıııdır. & 1 \\
\hline Hem öğretmen, hem öğrenci hem de ders açısından yapıcı ve geliştiricidir. & 1 \\
\hline Dersin amaçlarına kısmen de olsa ulaşılmıştır. & 1 \\
\hline Sistemli ve programlı bir öğretim anlatılmıştır. & 1 \\
\hline
\end{tabular}

Tablo 1'de görüldüğü gibi, doktora öğrencilerinin büyük bir bölümü Öğretimde Planlama ve Değerlendirme dersinin amaçlarına yönelik olumlu bir düşünceye sahiptirler. Özellikle bu dersin öğrencilere hitap edecek insanlar için önemli, gerekli ve başarılı bir ders olduğu vurgulanmıştır. Bu konuda görüş bildiren K9, “dersin en önemli amacı olan, eğitmenlerin sahip olduğu bilgiyi öğrencilere aktarabilmesinin sağlanmasını gerçekleştirdiğini düşünüyorum...." biçiminde ifade ederken K24'de bu görüşü destekleyecek biçimde “bu dersin amacı ileride herbiri ögrretme sürecine katılacak olan adaylara bu alandaki temel kavramları tanıtmaktır. Bu anlamda ders amacına ulaşmıştır......" Yine K3," bu dersin öğrencilere hitap edecek insanlar için çok gerekli ve önemli bir ders olduğunu düşünüyorum" diyerek dersin ileride öğretici olacak bireylere katkı sağladığını vurgulayarak açıklamışlardır. Bununla birlikte, dersin amaçlarına ulaştığı, ya da amaçların etkili, yeterli ve uygun olduğu da vurgulanan diğer 
noktalardan birisidir. K20, “dersin amacına ulaştığını ve kazandırılmak istenen davranışların çok iyi bir şekilde kazandırıldı̆̆ını düşünüyorum...." diyerek net bir bakış açısı sunmuş yine K28'de “amacına ulaşan bir ders...” olarak bu düşünceyi desteklemiştir.

Öğretimde Planlama ve Değerlendirme dersini uygulamaya yönelik olumlu biçimde değerlendiren görüşlerin yanında özellikle uygulamaya yönelik amaçların arttırılması yönünde görüş bildirenler olmuştur. K19, “.........ancak dersin işleniş biçiminin uygulamaya izin vermemesi sadece kuramsal ve tanımsal bilgilerle sınırlı kalması dersin amacı açısından eksiklik taşımaktadır” diyerek doğrudan dersin amaçlarına vurguda bulunmuştur. Yine, K1, “dersin içeriği faydalıydl ancak diğer bölümlere nazaran tiyatro bölümünde daha pratiğe dayalı bir öğretim yapılmakta. Bu ĕgitime yönelik bilgilere yer verilmesi güzel olabilir.” diyerek kendi alanı ile dersin ilişkisini arttıracak bir öneri getirmiştir. Öğretimde Planlama ve Değerlendirme dersine yönelik olumsuz ya da farklı bir bakış açısını vurgulayan K56, “.....dönem sonunda ulaşılmak istenen amaçlara kısmen de olsa ulaşıldı.” biçiminde görüşünü açıklamıştır, ancak bunu açıklamamıştır. Sonuç olarak, doktora öğrencilerinin büyük bir çoğunluğunun dersin amaçlarını olumlu buldukları söylenebilir.

\section{Öğretimde Planlama ve Değerlendirme Dersinin İçeriğine Yönelik Görüşler İle İlgili}

\section{Bulgular}

Araştırmada öncelikle Öğretimde Planlama ve Değerlendirme dersinin içeriğine yönelik doktora öğrencilerine görüşleri sorulmuş, ortaya çıkan yanıtlara Tablo 2'de yer verilmiştir. 
Tablo 2

Öğretimde Planlama ve Değerlendirme Dersinin Iç̧eriğine Yönelik Görüşler

\begin{tabular}{|c|c|}
\hline İçeriğe ilişkin Görüşler & $f$ \\
\hline İçerik yeterlidir. & 14 \\
\hline İçerik çok faydalıdır ve ilgi çekicidir. & 6 \\
\hline İçerik zengin ve keyiflidir. & 5 \\
\hline Genel bir içerik bulunmaktadır. & 4 \\
\hline İçerik eksikliğini yaşadığımız konulardan oluşmaktadır. & 3 \\
\hline Dersin içeriği verimlidir. & 3 \\
\hline Akademik güncel hayatta kullanilabilecek kavramlar bulunmaktadir. & 3 \\
\hline İ̧̧erik anlaşilırdır. & 3 \\
\hline Her alana uygulanabilir açı ve nettir. & 3 \\
\hline Ders içeriği dolu ve işlevseldir. & 3 \\
\hline Dersin içeriği amaçlara uygundur. & 3 \\
\hline Dersin içeriği çok yönlüdür. & 3 \\
\hline Dersin içeriği derse uygundur. & 2 \\
\hline İçerik yoğundur. & 2 \\
\hline İçerikte düzenli bir sira izlendi. & 1 \\
\hline İçeriğe uygun yöntem ve teknikler kullanıldı. & 1 \\
\hline İçerik bütün olarak mantıksal düzenlenmiştir. & 1 \\
\hline Olması gereken bilgilere yer verilmiş, gereksiz bilgiden uzaktır. & 1 \\
\hline SIkıcı olmayan bir içerik bulunmaktadır. & 1 \\
\hline Ölçme ve değerlendirme konuları arttırlabilir. & 1 \\
\hline Ders içeriğinde kuram ve uygulama oranı iyi ayarlanmıştır. & 1 \\
\hline Dersin içeriği öğrencilere çok şey kazandırmaktadır. & 1 \\
\hline İçerik uygun zamanda işlendi. & 1 \\
\hline Uygulama süresinin arttırIIması önerilebilir. & 1 \\
\hline
\end{tabular}

Tablo 2'de görüldüğü gibi doktora öğrencilerinin Öğretimde Planlama ve Değerlendirme dersinin içeriğine yönelik genel olarak olumlu görüşleri olduğu söylenebilir. Özellikle en çok dersin içeriğinin yeterli olduğu yönünde görüşün ifade edildiği görülmektedir. Buna yönelik, K3 “Bu ders içerik olarak oldukça yeterliydi. Illeride kullanabileceğimiz güncel öğrenme ve ögretme stratejilerinden haberdar olmamızı să̆ladı..." biçiminde ifade ederken K69, “...dersin kapsamında işlenen konular öğrenme süreci açısından bakış açısını genişletmektedir. Farkl öğrenme yöntemleri ve öğrenmeye yönelik kuramlar planlama sürecine yönelik bilgiler öğrenmemiz sürecin etkinliğini göstermektedir.." gibi açıklanan görüşlerde yeterliliğe vurgu yapmanın yanında özellikle içerikte ele alınan konulara değinildiği ve bunların nasıl kullanılacağı ile ilgili bilgi verildiği dikkat çekmektedir. Bununla birlikte, 
Anadolu Journal of Educational Sciences International, January 2016, 6(1)

dersin amacı doğrultusunda görüş bildiren K40 ise "ders içeriğinin nasıl belirleneceğinin anlatıldı̆̆ bir dersin içeriğinde hata olamaz, olmamalı. Zaten yoktu bence...” diyerek dersin içeriğinin yeterli olduğuna yönelik başka bir biçimde dikkat çekmektedir.

Verilen içeriğin özellikle akademik yaşama katkı sağladığı yönünde yapılan vurguyu K16, "Ders akademik ve güncel hayatta kullanılabilecek temel kavramları yeterince içeriyor..." biçiminde ifade ederken K51 ise "İçerik oldukça kapsamlı ve detaylı. Buna karşılık, bir o kadar da kullanışlı bilgiler. Akademik hayatta ögrenci ve ögrretmen açısından oldukça geliştirici. “ biçiminde görüşleriyle söylenenleri desteklemektedir.

Tüm bunlara göre, Öğretimde Planlama ve Değerlendirme dersinin içeriğine yönelik doktora öğrencilerinin olumlu görüş taşıdıkları söylenebilir.

\section{Öğretimde Planlama ve Değerlendirme Dersinin Öğrenme- Öğretme Sürecine Yönelik}

\section{Görüşler İle İlgili Bulgular}

Araştırmada öncelikle Öğretimde Planlama ve Değerlendirme dersinin öğrenme- öğretme sürecine yönelik doktora öğrencilerine görüşleri sorulmuş, ortaya çıkan yanıtlarına Tablo 3'te yer verilmişstir. 
Anadolu Journal of Educational Sciences International, January 2016, 6(1)

Tablo 3

Öğretimde Planlama ve Değerlendirme Dersinin Öğrenme- Öğretme Sürecine Yönelik Görüşler

\begin{tabular}{|c|c|}
\hline Öğrenme-Öğretme Sürecine ilişkin Görüş̧ler & f \\
\hline Dersin online olması olumludur. & 12 \\
\hline Dersin yüzyüze olması gereklidir. & 9 \\
\hline Etkileşime dayalı bir ders gerçekleştirilmiş̧ir. & 8 \\
\hline Dersin öğretme süreçlerine yönelik başarılı stratejiler kullanılmıştır. & 6 \\
\hline Ders verimliydi. & 4 \\
\hline Uzaktan öğretim olmasına karşılık içerik ve öğretme süreçleri ilgimi çekmiştir. & 3 \\
\hline Online olması ilginin dağılmasına neden oluyor. & 3 \\
\hline Öğrenme-öğretme süreçleri uygundur. & 3 \\
\hline Online sistemde sorunlar yaşanabiliyor. & 3 \\
\hline Dersin çevrimiçi ve yüzyüze alternatifleri olmalıdır. & 3 \\
\hline Materyaller zamanında sisteme yüklendi. & 3 \\
\hline Ders içeriği uygulama alanı ile ilişkilendirildi. & 3 \\
\hline Ders açık, net ve anlaşılır biçimde işlendi. & 3 \\
\hline Öğrencilerin aktif katılım sağlanmıştır. & 3 \\
\hline Eş zamanlı katılım online dersin olumsuzluğunu kaldırmaktadır. & 3 \\
\hline Online ortamda pek çok etkinlik gerçekleştirildi. & 3 \\
\hline Öğreticinin bilgisinin yeterli oluşu süreci olumlu etkiledi. & 3 \\
\hline Dersin işlenişi başarılıydı. & 2 \\
\hline Dersin işlenişinde önemli olan öğreticidir. & 2 \\
\hline Dersin online olması hem avantaj hem dezavantajdır. & 2 \\
\hline Akademik yaşam için farkındalık sağlanmıştır. & 2 \\
\hline Dersin öğretme-öğrenme sürecinde örtük programın başarısı tartışılmazdır. & 1 \\
\hline
\end{tabular}

Tablo 3’te görüldüğü gibi, doktora öğrencileri Öğretimde Planlama ve Değerlendirme dersinin öğrenme - öğretme sürecinde çevrimiçi ya da yüzyüze ortamda olmasına yönelik daha belirgin biçimde görüş belirtmişlerdir. Dersin online ortamda olmasını olumlu bulanlar buna yönelik olarak değişik noktalara dikkat çekmişlerdir. K33, “...amaç ve içerik olarak oldukça yoğundolu olan bu dersimizin uzaktan ĕgitimle verilmesi, benim gibi şehir dlşııdan gelip giden birisi için büyük kolaylık......" biçiminde belirterek uzaktan aldığı bu dersin ulaşım kolaylığından sözederken, K34 ise, “...ders genel olarak uzaktan öğretim ile yürütülmektedir. Doktorantların iş yükleri ve aday sayısının çokluğundan dolayı bu yöntemin uygun bir yöntem olduğunu düşünmekteyim. Bu noktada uzaktan eğitim sonucu kazanılan becerilerin uygulamaları da gerçekleştirilmiştir..” diyerek Öğretimde Planlama ve Değerlendirme dersinin online ortamda 
yürütülmesine yönelik farklı bir bakış açısı ortaya koymuştur. K39 ise "Şahsım adına gayet verimli geçti. Hem uzaktan olması hem istediğim zaman dersleri tekrar edebilmem için benim için faydalı oldu." diyerek derslerin tekrar edilmesine yönelik vurgu yapmıştır.

Öğretimde Planlama ve Değerlendirme dersinin yüz yüze gerçekleştirilmesi gerektiği öne çıkan bir diğer görüştür. K4, bu konuda “..dersin yüzyüze yapılması gerekiyor. Online ders dinlerken tam olarak konuya odaklanamıyorum. Öğreticiyi görmenin önemli olduğunu düşünüyorum.....” biçiminde özellikle online dersin dikkatin yoğunlaştırılması konusunda sorun oluşturduğunu belirtirken, K59 “..Öğrenme- öğretme sürecinde yüzyüze eğitim daha faydalı olabilir..” yüzyüze derslerin faydalı olacağını belirtmiştir. Bununla birlikte, online derslerin etkileşime dayalı olduğunu vurgulayanlar da oldukça çoktur. K50, "Öğretimde planlama ve değerlendirme dersinin öğrenme- öğretme süreci online olarak gerçekleşmiştir. Tüm süreç boyunca dersi veren hocamız ile birebir etkileşimde kalabildik. Online bir ders olmasına rağmen hocamız sanki yüzyüze eğitim veriyormuşcasına tüm öğrencilerle tek tek ilgilendi, hepimizi tanıdı. Sadece düz anlatım olarak geçebilecekken bilgisayar başında pekçok etkinlik gerçekleştirdik” biçiminde görüşünü açıklarken, K44, “Öğrencilerin aktif katılımının sağlandığı açılayıcı anlatım ile dolu dolu işlendi. Dönütlere özen gösterildi” diyerek aktif katılım ve dönüte vurgu yapmıştır.

Bununla birlikte K43, “Dersin online olması ilk başta tedirginlik yaratsa da öğrenme- ögretme sürecindeki örtük programın başarısı tartışılmazdır. Ders programında da bir aksaklık yaşandığını düşünmüyorum.....” diyerek program açısından oldukça önemli bir kavram olan örtük programa değinmiş ve bunu öğrenme süreci ile ilişkilendirmiştir. Bu dikkat çekici bir diğer noktadır. 
Sonuç olarak, doktora öğrencilerinin Öğretimde Planlama ve Değerlendirme dersinin öğrenmeöğretme süreçlerini özellikle çevrimiçi öğrenme ortamları açısından ele aldıkları ve görüşlerinde ise öğrenme ortamının temel değişkenlerini ele alarak görüşlerini açıkladıkları söylenebilir.

\section{Öğretimde Planlama ve Değerlendirme Dersinin Değerlendirme Sürecine Yönelik}

\section{Görüşler İle İlgili Bulgular}

Araştırmada öncelikle Öğretimde Planlama ve Değerlendirme dersinin değerlendirme sürecine yönelik doktora öğrencilerine görüşleri sorulmuş, ortaya çıkan yanıtlarına Tablo 4'te yer verilmiştir.

Tablo 4

Öğretimde Planlama ve Değerlendirme Dersinin Değerlendirme Sürecine Yönelik Görüşler

\begin{tabular}{|l|l|}
\hline Değerlendirme Stirecine ilişkin Görüşler & $f$ \\
\hline Ödevler anlatılan konuları pekiştirdi. & 8 \\
\hline Sinavlar öğrendiklerimizi sınayacak nitelikteydi. & 8 \\
\hline Değerlendirme yeterliydi. & 8 \\
\hline Değerlendirme dersin amacına ve iç̧riğine uygundur. & 8 \\
\hline Bilgiyle birlikte yorum gerektiren sorulara yer verildi. & 8 \\
\hline Kendimizi anlatma imkanı sağlandı. & 6 \\
\hline Ödevler ve katlımın değerlendirmeye dahil edilmesi olumludur. & 3 \\
\hline Değerlendirme bizim süreçleri içselleştirmemizle ilgiliydi. & 3 \\
\hline Değerlendirme süreçlerinde bizim görüşlerimize başvuruldu. & 3 \\
\hline Değerlendirme süreci olumludur. & 3 \\
\hline Değerlendirme quizler biçiminde yapılabilir. & 3 \\
\hline Değerlendirme objektifdir. & 3 \\
\hline Yorum soruları bu ders için anlamlıydı. & 3 \\
\hline Ödevler tek tek incelenip dönüt verilmiştir. & 3 \\
\hline lyi bir değerlendirmenin nasıl yapılması gerektiğini öğrendim. & 3 \\
\hline Değerlendirme doğru ve tarafsız olarak gerçekleşmiştir. & 3 \\
\hline Derste süreç değerlendirmegerçekleşti. & 3 \\
\hline Değerlendirme sürecinde olan tüm konular işlenmiştir. & 2 \\
\hline
\end{tabular}


Tablo 4'te görüldüğü gibi, değerlendirme sürecinin niteliğine, kapsamına, yorumlanışına ve özelliklerine yönelik görüşler bildirilmiştir. Bu görüşlerin içerisinde değerlendirme içerisinde yer alan ödevlere yönelik olumlu açıklamalar bulunmaktadır. K41, “.......dersi geçip kalmadan çok ödeve ve derse katılmaya odaklandım ve bence sınava yönelik olup sınavdan hemen sonar unutacă̆ımdan çok daha fazlasını öğrendim....." biçiminde görüşlerini açıklarken K56, “Ödevlere zamanında ve uygun dönütler verildi......" bu görüşü destekleyici açıklamalarda bulunmuştur. Bununla birlikte, değerlendirmenin yorum soruları ile gerçekleştirilmesini vurgulayan K2, “Değerlendirme sürecinde klasik olarak sorulan sorular çok daha önemliydi. Kendimizi anlatma fırsatı tanınmış oldu...." diyerek değerlendirmede kullanılan soruların kendisini anlatmak için bir yol olduğunu vurgulamıştır. Yine, K13 ise "Slnavlarda sorulan yorum soruları gerçekten birşeyler öğrenip öğrenmediğimizi sınamak adına tam olması gerektiği gibi...” diyerek sorulan soruların işlevine yönelik bir bakış açısı oluşturmuştur.

Değerlendirme sürecinin kişilerin alanı ile ilişkilendirildiği ile ilgili görüş bildiren $\mathrm{K} 17$ " $\mathrm{Bu}$ dersin değerlendirme sürecinde hocamız bizim neyi ne kadar öğrendiğimiz ve bildiğimizden çok, içselleştirip kendi bölümümüzle ne kadar bağdaşdırdığımızla daha çok değerlendirdi ve sınavları buna göre planladı diye düşünüyorum. Bu da daha çok etkili ve anlamlı oldu...” diyerek bu durumu oldukça ayrıntılı açıklamıştır.

Sonuç olarak, doktora öğrencilerinin Öğretimde Planlama ve Değerlendirme dersinin değerlendirme süreçlerini olumlu bir bakış açısı ile yeterli olarak nitelendirdikleri söylenebilir.

\section{Sonuç, Tartışma ve Öneriler}

Çevrimiçi öğrenme ortamları öğrenme süreçleri açısından gelişen ve değişen teknolojilerin izlenmesini sağlayan etkili ve nitelikli öğrenme ortamlarının sağlanması açısından destekleyici 
bir yapıya sahiptir. Bu çalışma, çevrimiçi öğrenme ortamında Eğitim Bilimleri Enstitüsü dışındaki enstitülere devam eden doktora öğrencilerinin Öğretimde Planlama ve Değerlendirme dersinin amaç, içerik, öğrenme- öğretme süreci ve değerlendirme süreçlerine yönelik görüşlerini almak amacıyla gerçekleştirilmiştir. Çalışmada Öğretimde Planlama ve Değerlendirme dersinin öğreticilerin yetiştirilmesi için gerekli, etkili, ulaşılabilir ve önemli amaçlara sahip olduğu yönünde bulgulara ulaşılmıştır. Bir başka deyişle, dersin öğrencilerin gereksinimlerini dikkate alan bir yapısının olduğu söylenebilir. Bununla birlikte, Tanyıldızı ve Semerci (2005) yaptıkları çalışmada öğretim elemanlarının çevrimiçi öğrenme ortamlarının başarılı olduğu yönünde, öğrencilerin ise çevrimiçi öğrenme ortamına yönelik olarak geleneksel öğrenme ortamlarından çok farklı olmadığı biçiminde görüş bildirdikleri sonucuna ulaşmışlardır. Bu çalışmanın sonuçları ile tutarlılık göstermemektedir.

Araştırmada ulaşılan bir diğer sonuç ise, Öğretimde Planlama ve Değerlendirme dersinin içeriğinin öğrenci gereksinimlerini karşılayan yeterli, kapsamlı ve genel bir içeriğe sahip olduğu biçimindedir. Buna göre, dersin amaçlarına bağlı olarak içeriğinin hedef kitlenin özellikleri bağlamında belirlendiği, özellikle "iyi bir öğretici nasıl olmalıdır” sorusunu gözönünde bulundurduğu biçiminde yorumlanabilir.

Doktora öğrencilerinin Öğretimde Planlama ve Değerlendirme dersinin öğrenme- öğretme sürecine yönelik olumlu düşünceleri olmakla birlikte, dersin yüzyüze yapılması ya da online ya da çevrimiçi olmasının tercihe bırakılması yönünde görüş bildirdikleri sonucuna ulaşılmıştır. Bununla birlikte, özellikle yüz yüze etkileşimi isteyenlerin özellikle öğretici ile yüz yüze olmanın etkileşim açısından önemini vurguladıkları görülmektedir. Uzaktan eğitimle ilgili yapılan çalışmalar, çevrimiçi öğrenme ortamlarında öğrenen özellikleri ve beklentilerine gerekli özen gösterilmediğinde öğrenme sürecinde zorluklar yaşanabildiğini göstermektedir. 
Bununla birlikte, öğrencilerin temel bilgisayar kullanma bilgi ve becerisine sahip olmaları, bilgisayar özyeterlik algılarının yüksek düzeyde olması ve kendi öğrenmeleriyle ilgili sorumluluk almaları çevrim-içi öğrenme ortamlarının başarılı olmasında belirleyici olan diğer değişkenler olarak nitelendirilmektedir (Çelen, Çelik ve Seferoğlu, 2011).

Araştırma kapsamındaki doktora öğrencilerinin Öğretimde Planlama ve Değerlendirme dersinin değerlendirme süreçlerine yönelik çoğunlukla kapsamı, özellikleri, süreçleri ve gerçekleştirilmesi açısından olumlu görüşlere sahip oldukları belirlenmiştir. Özellikle amaçlara uygun değerlendirmenin gerçekleştiği sıklıkla vurgulanan özellikleri arasında yer almaktadır.

Tüm bu sonuçlara dayalı olarak, Öğretimde Planlama ve Değerlendirme dersinin en başta açıklanan genel amacına yönelik bir ders olduğu, ancak uygulama süreçleri açısından çevrimiçi ortamda yürütülmesinin yanında yüz yüze eğitime de olanak sağlayacak harmanlanmış öğrenme süreçleri ile yürütülmesinin hedef kitlenin gereksinimlerini etkili bir biçimde gerçekleştirmek açısından daha uygun olduğu söylenebilir. Bununla birlikte, bu araştırmanın özellikle özyeterlik algısı, cinsiyet gibi değişkenlerle ilişkilendirilerek gerçekleştirilmesi önerilebilir.

\section{Kaynakça}

Aydın, C. H. (2002). Çevrimiçi (Online) Öğrenme Toplulukları. Açıköğretim Fakültesi 20. Kuruluş Y11ı Nedeniyle Uluslararası Katkılı Açık ve Uzaktan Eğitim Sempozyumunda Sunulan Bildiri.

Bender, T. (2003). Discussion-Basen Online Teachning. To Enhance Student Learning: Theory, Practice and Assessment. Virginia: Stylus Publishing.

Chorfi, H. ve Jemni, M. (2004). PERSO: Towards and adaptive e-learning system. Journal of Interactive Learning Research, 15(4). 28.12. 2015 tarihinde 
Anadolu Journal of Educational Sciences International, January 2016, 6(1)

http://www.editlib.org/INDEX.CFM?fuseaction=Reader.ViewFullText\&paper_id=1890 0 adresinden erişilmiştir.

Çardak, Ç. S. (2012). Harmanlanmış Öğrenme Sürecinde Öğrencilerin Etkileşimlerinin ve Öğrenme Düzeylerinin İncelenmesi. Yayımlanmamış Doktora Tezi, Anadolu Üniversitesi Eğitim Bilimleri Enstitüsü. Eskişehir.

Çalışkan, H. (2002). Çevrimiçi (Online) Eğitimde Öğrenci Etkileşimi. Açıköğretim Fakültesi 20. Kuruluş Y1lı Nedeniyle Uluslararası Katkılı Açık ve Uzaktan Eğitim Sempozyumunda Sunulan Bildiri.

Çelen, F. K., Çelik, A. ve Seferoğlu, S. S. (2011). Yükseköğretimde çevrim-içi öğrenme: Sistemde yaşanan sorunlar ve çözüm önerileri. Journal of European Education, 1(1), 2534.

Demirel, Ö. (2004). Öğretimde Planlama ve Değerlendirme - Öğretme Sanat1. Ankara: PEGEM Yayıncilık.

Gülbahar, Y.(2009). E-Öğrenme. Ankara: Pegem Akademi.

Karasar, N. (2015). Bilimsel araştırma yöntemi. 28.basım. Ankara: Nobel Yayın Dağıtım.

Miles, M. ve Huberman, M. (1994). Qualitative Data Analysis. İkinci Basım. USA: Sage Publications.

Senemoğlu, N. (1997). Gelişim, Öğrenme ve Öğretim. Ankara.

Tanyıldızı, M. ve Semerci, Ç. (2005). Çevrimiçi eğitim uygulamalarına ilişkin öğretim elemanı ve öğrenci görüşlerinin belirlenmesi. Türk Ĕ̆itim Bilimleri Dergisi, 3(2), 192-216.

Yıldırım, A. ve Şimşek, H. (2013). Sosyal Bilimlerde Nitel Araştırma Yöntemleri. 9. Basım. Ankara: Seçkin Yayıncılık.

YÖK. (1998). Eğitim fakülteleri öğretmen yetiştirme programlarının yeniden düzenlenmesi raporu, Ankara. www.yok.gov.tr. 


\section{Extented Abstract}

In the ever-changing and globalizing world, new traits have been added to the characteristics that were previously expected from individuals to acquire, which can be stated as being in search of knowledge, able to inquire, solve problems, think critically, learn how to learn, utilize technology effectively and express himself clearly. The employment conditions of our era have a distinctive role in determining which knowledge and skills individuals should have. That the instructors, who are considered to have an important function in improving these knowledge and skills, are comprised of individuals who can understand the changes and developments, interpret them and internalize efficiency and quality is an important expectation in terms of ensuring quality in educational services. As swift changes occur in technology, the technical skills individuals have can easily lose their up-to-dateness. In catering the needs of individuals who seek for these knowledge and skills, online learning environments through which

continuous, flexible and uninterrupted instruction is delivered can be used effectively. Online learning refers to a learning context in which the content, teaching activities and learning experiences are delivered to the students via computer networks. 'Development and Learning' and 'Instructional Planning and Evaluation' courses, which are compulsory for the $\mathrm{PhD}$ students except for those studying in the Institute of Educational Sciences based on the decision of the Council of Higher Education, are conducted online in the fall and spring semesters in Anadolu University. These courses taken by the PhD students of both Anadolu University and other universities aim to prepare the $\mathrm{PhD}$ candidates to be able to teach at universities as a faculty member. The skills needed to be an instructor are quite comprehensive and covers a lot of basic skills like determining the aims of the lesson and evaluating the students. Revealing how the doctoral students of institutes -except for Institute of Educational Sciences- evaluate online 'Instructional Planning and Evaluation' course which aims to their basic instructional 
skills bears importance. Along with this, the fact that there is no study focusing on this topic constitutes another reason why this study is carried out. The aim of this study is to reveal the students' opinions on the aim, content, learning-teaching processes, and evaluation processes of the online 'Instructional Planning and Assessment' course. This survey research was conducted with the voluntary participation of $69 \mathrm{PhD}$ students who took the 'Instructional Planning and Assessment' online course offered by Anadolu University Institute of Educational Sciences in 2014-2015 fall and spring semesters. In this research, the data collected through open-ended questionnaires were analyzed with descriptive data analysis technique. As a result of the study, doctoral students stated positive opinions about the aims, content, learningteaching process and evaluation processes of 'Instructional Planning and Evaluation' course. Doctoral students stated that the aims of the course are sufficient, effective, comprehensible and reachable; the content of the course is useful, interesting, comprehensible, clear and sufficient; the online learning-teaching process is positive, clear, interaction-based and informative; evaluation of the course is sufficient, congruent with the aims and objective. 